\title{
Enhancement of USGS Scientific Investigations in Texas by Using Geophysical Techniques, 2005-10
}

\section{Introduction}

Geophysical techniques are an increasingly important tool for scientific investigations, environmental planning, and resource management. During 2005-10 the U.S. Geological Survey (USGS) Texas Water Science Center (TXWSC) greatly expanded its capabilities of using surface and borehole geophysical techniques to gain insights into how groundwater systems work and the occurrence and distribution of certain contaminants. Geophysical techniques provide a relatively quick and inexpensive means to characterize the subsurface hydrology and lithology.

Surface and borehole geophysical methods are used to measure the physical properties of the subsurface, such as electrical conductivity or resistivity, dielectric permittivity, magnetic permeability, density, and acoustic velocity. Geophysical measurements can be influenced by chemical and physical properties of soils, rocks, and pore fluids. Interpretations from these measurements can be used to image the distribution of physical properties in the subsurface. Surface and borehole geophysical methods and their application to groundwater and environmental investigations are described in detail in Zohdy and others (1974), Keys (1990), and U.S. Army Corps of Engineers (1995).

This report describes the technical capabilities and project activities of the TXWSC geophysical workgroup during 2005-10. After a brief summary of the geophysical workgroup's capabilities, the details of project activities are described. Projects are grouped by the primary techniques used and include overviews, project images, and Internet links to additional project material and related publications.

\section{Geophysical Workgroup Skills and Capabilities}

The TXWSC geophysical workgroup consists of geophysicists and hydrologists who specialize in surface and borehole geophysical techniques. The workgroup collaborates with resident natural resource scientists on a diverse range of projects. There is emphasis on technical training to keep skills current with advances in software and technology. The workgroup's technical capabilities include but are not limited to the following:

- Borehole logging techniques

o Natural gamma

o Electromagnetic induction

o Long and short normal resistivity

o Heat pulse and electromagnetic flow meter

o Neutron density

o Acoustic and optical televiewer

o Fluid resistivity/conductivity

o Full wave sonic
- Surface geophysical methods

o Frequency-domain electromagnetics

o Time-domain electromagnetics

o Capacitively coupled electromagnetics

o Direct-current resistivity

o Magnetic resonance soundings

o Ground-penetrating radar

The geophysical workgroup actively participates and collaborates with local, State, national, and international members of the environmental geophysical community. In addition, it regularly contributes to the knowledge base through presentations and publications.

\section{Example Applications of Geophysical Techniques}

Geophysical project activities of the TXWSC have steadily increased over the past 10 years. All projects mentioned below (fig. 1) have a substantial geophysical component. Each of the projects listed was published during 2005-10. This is not a complete list of projects, but it highlights examples of several geophysical techniques and their applications.

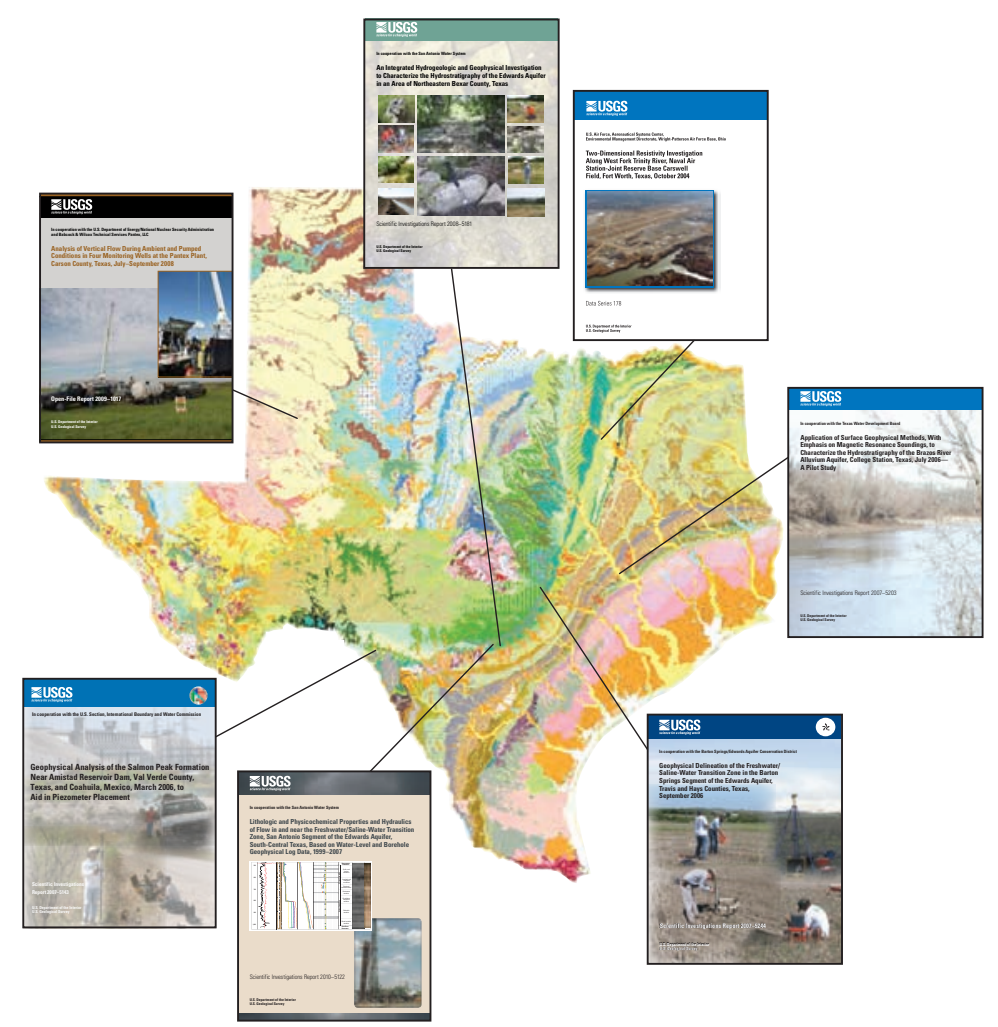

Figure 1. Map showing the cover page of each report presented in this report. Lines point to approximate location of each study. 


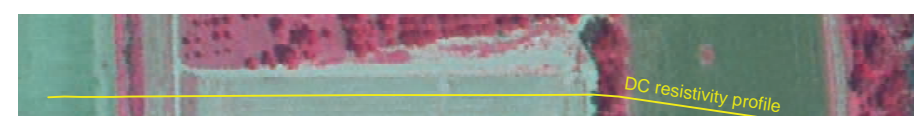

\section{Surface Geophysical Techniques}

\section{Direct Current Resistivity}

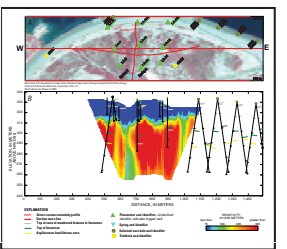

Geophysical Analysis of the Salmon Peak Formation near Amistad Reservoir Dam, Val Verde County, Texas, and Coahuila, Mexico, March 2006, to Aid in Piezometer Placement

In 1995 the Mexico Section of the International Boundary and Water Commission (IBWC) completed a study (including surface geophysics, borehole geophysics, and installation of piezometers) of subsurface conditions of the western embankment (Coahuila, Mexico) of Amistad Reservoir Dam. Technical advisors recommended that one line of similarly constructed piezometers be installed on the eastern embankment of the dam for comparison of water levels (potentiometric head) on both the western and eastern embankments of the dam. To provide technical assistance for the horizontal and vertical placement of piezometers on the eastern embankment of Amistad Reservoir Dam, the USGS, in cooperation with the U.S. Section of the IBWC, conducted a study along both the western and eastern embankments of Amistad Reservoir Dam. The study involved an integrated approach using surface and borehole geophysical methods. In the western embankment investigation, geological and geophysical characteristics that indicate relatively large water-yielding properties of the Salmon Peak Formation were identified. The directcurrent (DC) resistivity method was selected as the surface geophysical reconnaissance technique to correlate relatively large water-yielding properties of the Salmon Peak Formation, identified from analysis of borehole geophysical logs, with variations in subsurface resistivity. The correlation of surface geophysical DC resistivity, historical lithologic data, and general trend of documented sinkholes along the eastern end of the eastern embankment profile was used to justify further exploration (drilling of piezometers). The spatial location of the piezometers and screened intervals were selected to best match the locations of the screened intervals of the western embankment piezometers.

- USGS Scientific Investigations Report 2007-5143: http:// pubs.usgs.gov/sir/2007/5143/

\section{Capacitively Coupled Resistivity}

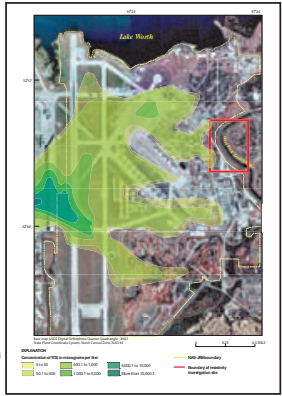

Two-Dimensional Resistivity Investigation Along West Fork Trinity River, Naval Air Station-Joint Reserve Base Carswell Field, Fort Worth, Texas, October 2004

The USGS, in cooperation with the Naval Air Station-Joint Reserve Base Carswell Field (NAS-JRB) at Fort Worth, Tex., conducted a 2D resistivity investigation at a site to characterize the distribution of subsurface resistivity. Contaminants, primarily volatile organic compounds and metals, have entered the groundwater flow system through leakage from waste-disposal sites and manufacturing processes. The Goodland Limestone and the underlying Walnut Formation form a confining unit that underlies the alluvial aquifer. The bedrock confining unit is the zone of interest because of the potential for contaminated groundwater to enter the river through saturated bedrock. The study involved a capacitively coupled resistivity survey and inverse modeling to obtain true or actual resistivity from apparent resistivity.

- USGS Data Series Report 178-06: http://pubs.usgs.gov/ $d s / d s 178 /$

\section{Magnetic Resonance Soundings}

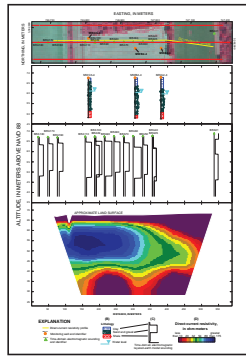

Application of Surface Geophysical Methods, With Emphasis on Magnetic Resonance Soundings, to Characterize the Hydrostratigraphy of the Brazos River Alluvium Aquifer, College Station, Texas, July 2006-A Pilot Study

The USGS, in cooperation with the Texas Water Development Board, used surface geophysical methods in a pilot study to characterize the hydrostratigraphic properties of the Brazos River alluvium aquifer at the Texas A\&M University Brazos River Hydrologic Field Research Site near College Station, Texas, and determine the effectiveness of the methods to aid in generating an improved groundwater-availability model. Three noninvasive surface geophysical methods were used to characterize the electrical stratigraphy and hydraulic properties and to interpret the hydrostratigraphy of the Brazos River alluvium aquifer. Two methods, time-domain electromagnetic (TDEM) soundings and twodimensional direct-current (2D-DC) resistivity imaging, were used to define the lateral and vertical extent of the near-surface hydrogeologic zones. Magnetic resonance sounding (MRS), a recently developed geophysical method, was used to derive estimates of the hydrologic properties including percentage water content and hydraulic conductivity. Results from the geophysics study demonstrated the usefulness of combined TDEM, 2D-DC resistivity, and MRS methods to reduce the need for additional boreholes in areas with data gaps and to provide more accurate information for groundwater availability models.

- USGS Scientific Investigations Report 2007-5203: http:// pubs.usgs.gov/sir/2007/5203/

\section{Time-Domain Electromagnetics}

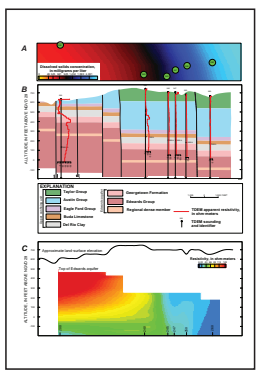

Geophysical Delineation of the Freshwater/ Saline-Water Transition Zone in the Barton Springs Segment of the Edwards Aquifer, Travis and Hays Counties, Texas, September 2006

The USGS, in cooperation with the Barton Springs/Edwards Aquifer Conservation District, conducted a pilot geophysical study to use TDEM sound- 
ing to delineate the freshwater/saline-water transition zone of the Edwards aquifer in Travis and Hays Counties, Tex.. There was uncertainty regarding the application of TDEM sounding for this purpose because of the depth of the aquifer (200-500 feet to the top of the aquifer) and the relatively low-resistivity clayey units in the upper confining unit. Twenty-five TDEM soundings were made along four 2- to 3-mile-long profiles in a study area overlying the transition zone. The soundings yielded measurements of subsurface electrical resistivity, the variations in which were correlated with hydrogeologic and stratigraphic units, and then with dissolved-solids concentrations in the aquifer. On the basis of reasonably close matches between the inferred locations of the freshwater/saline-water transition zone from resistivities and from dissolved-solids concentrations in three of the four profiles, TDEM sounding appears to be a suitable tool for delineating the transition zone.

- USGS Scientific Investigations Report 2007-5244: http:// pubs.usgs.gov/sir/2007/5244/

\section{Frequency-Domain Electromagnetic Profiling}

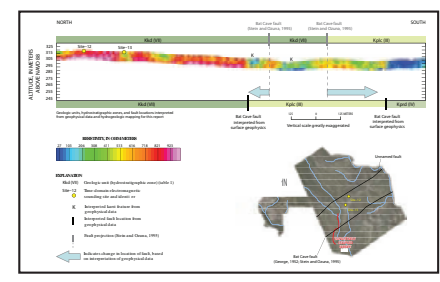

\section{An Integrated Hydrogeologic and Geophysical Investigation to Characterize the Hydrostratigraphy of the Edwards Aquifer in an Area of Northeastern Bexar County, Texas}

The USGS, in cooperation with the San Antonio Water System, did a hydrogeologic and geophysical investigation to characterize the hydrostratigraphy (hydrostratigraphic zones) and karst features (features such as sinkholes and caves) of the Edwards aquifer in a 6.2-squaremile area undergoing urban development. Existing hydrostratigraphic information, enhanced by local-scale geologic mapping in the area, and surface geophysics were used to associate ranges of electrical resistivities, obtained from capacitively coupled resistivity surveys, frequency-domain electromagnetic (FDEM) surveys, TDEM soundings, and 2D-DC resistivity surveys, with each of seven hydrostratigraphic zones of the Edwards aquifer. The principal finding of this investigation is the relation between electrical resistivity and the contacts between the hydrostratigraphic zones of the Edwards aquifer and the underlying Trinity aquifer in the area.

- USGS Scientific Investigations Report 2008-5181: http:// pubs.usgs.gov/sir/2008/5181/

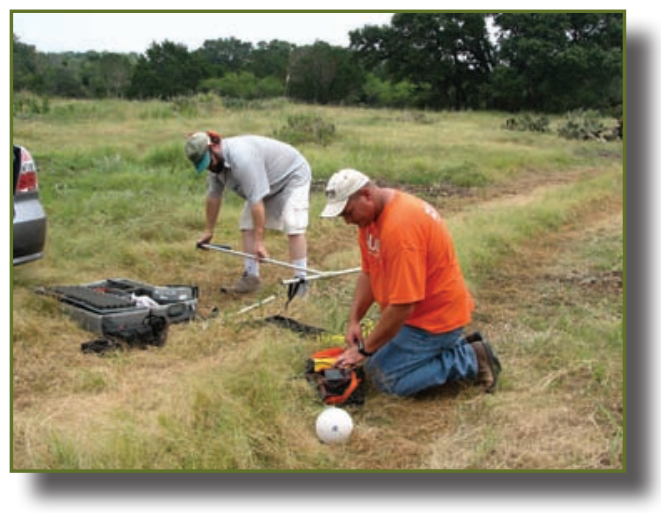

\section{Borehole Geophysical Techniques}

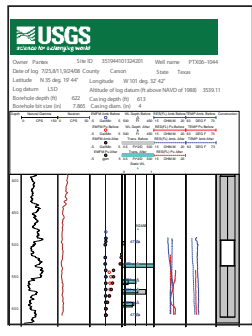

Analysis of Vertical Flow During Ambient and Pumped Conditions in Four Monitoring Wells at the Pantex Plant, Carson County, Texas, July-September 2008

The USGS, in cooperation with

B\&W Pantex, made a series of flowmeter measurements and collected other borehole geophysical logs during JulySeptember 2008 to analyze vertical flow in screened intervals of four selected monitoring wells at the Pantex Plant. Hydraulic properties (transmissivity values) of the section of the High Plains (Ogallala) aquifer penetrated by the wells also were computed. Geophysical data were collected under ambient and pumped flow conditions in the four monitoring wells. Unusually large drawdowns occurred at two monitoring wells while the wells were pumped at relatively low rates. A decision was made to redevelop those wells, and logs were run again after redevelopment in the two monitoring wells.

- USGS Open-File Report 2009-1017: http://pubs.usgs. gov/of/2009/1017/

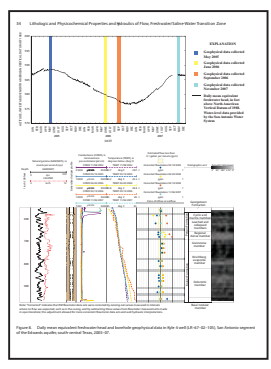

Lithologic and Physicochemical Properties and Hydraulics of Flow in and near the Freshwater/Saline-Water Transition Zone, San Antonio Segment of the Edwards Aquifer, South-Central Texas, Based on Water Level and Borehole Geophysical Log Data, 1999-2007

The freshwater zone of the Edwards aquifer in south-central Texas is bounded to the south and southeast by a zone of transition from freshwater to saline water (hereinafter, the transition zone). The boundary between the two zones is the freshwater/saline-water interface (hereinafter, the interface), defined as 1,000-milligrams per liter of dissolved solids. This report presents the findings of a study, done by the USGS in cooperation with the San Antonio Water System, to obtain lithologic properties and physicochemical properties and to analyze the hydraulics of flow in and near the transition zone of the Edwards aquifer on the basis of water level and borehole geophysical log data collected from 15 monitoring wells in four transects during 1999-2007. A hydraulic connection between the transition zone and the freshwater zone is indicated by similar patterns in the hydrographs of the 15 transect monitoring wells in and near the transition zone and three county index wells in the freshwater zone during 1999-2007. The data for this report support, in part, a conceptualization of regional flow in and near the transition zone in which water enters the transition zone from the freshwater zone in the western part of the Edwards aquifer, flows toward the northeast, and discharges to the freshwater zone in the eastern part of the aquifer. The data for this report support the hypothesis that the interface is likely to remain laterally and vertically stable over time.

- USGS Scientific Investigations Report 2010-5122: http:// pubs.usgs.gov/sir/2010/5122 


\section{References Cited}

Keys, W.S., 1990, Borehole geophysics applied to ground water investigations: U.S. Geological Survey Techniques of WaterResources Investigations, book 2, chap. E2, 150 p.

U.S. Army Corps of Engineers, 1995, Geophysical exploration for engineering and environmental investigations: Engineering Manual 1110-1-1802, chap. 4, 57 p.

Zohdy, A.A.R., Eaton, G.P., and Mabey, D.R., 1974, Application of surface geophysics to ground-water investigations: U.S. Geological Survey Techniques of Water-Resources Investigations, book 2, chap. D1, 116 p.

\section{Geophysical Workgroup Contact Information}

Gregory P. Stanton

Groundwater Specialist

1505 Ferguson Lane

Austin, Tx 78754

512-927-3558

Andrew P. Teeple

Hydrologist

944 Arroyo Street

San Angelo, Tx 76903

325-944-4600 x-17
Jason D. Payne

Geophysicist

944 Arroyo Street

San Angelo, Tx 76903

325-944-4600 x-28

Jonathan V. Thomas

Geophysicist

2775 Alta Mesa Blvd.

Fort Worth, Tx 76133

817-263-9545 x-228

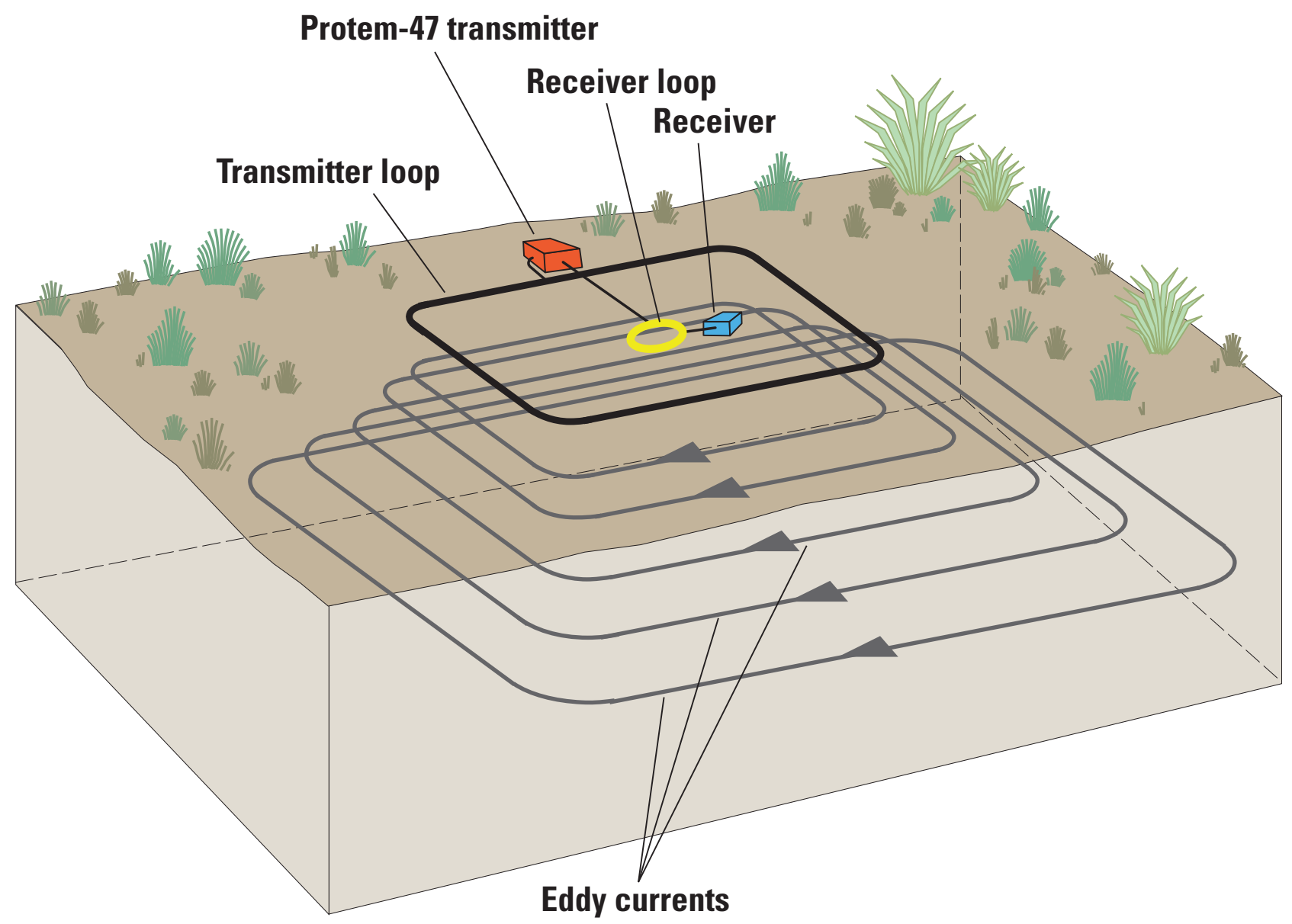

Time-domain electromagnetic sounding layout and operation

Publishing support provided by

Lafayette Publishing Service Center
For additional information, contact

Director

USGS Texas Water Science Center

http://tx.usgs.gov/

gs-w-txpublic-info@usgs.gov 